\title{
PUBLIC SPACE ZONING PATTERNS IN MIXED USE BUILDING POLA ZONING RUANG RUANG PUBLIK PADA BANGUNAN MIXED USE
}

\author{
Hikmah Purnama Sari' ${ }^{1}$, Gatoet Wardianto ${ }^{2}$ \\ Prodi Arsitektur, Fakultas Teknik, Universitas Pandanaran \\ hikmahpurnamasari8@gmail.com ${ }^{1)}$ \\ gatoet.w@gmail.com ${ }^{2)}$
}

\begin{abstract}
Abstrak
Inovasi dan kreativitas yang dibutuhkan untuk mengintegrasikan semua jenis, dan fungsi properti ke dalam satu kawasan pengembangan yakni mixed use development. Di Indonesia, konsep ini sejatinya sudah lama diterapkan, sekitar awal tahun 2000-an saat bisnis properti mengalami booming. Pada dasarnya, mixed use development adalah sebuah kawasan terintegrasi yang terdiri dari tempat tinggal, kantor, pusat perbelanjaan, dan fungsi urban lainnya. Beberapa kawasan mixed-use yang terkenal di Indonesia adalah kawasan ciputra world jakarta barat, kawasan central park jakarta selatan, kawasan plaza indonesia di jakarta pusat, kawasan gandaria city jakarta selatan dan distric 8 di jakarta selatan. Seperti kawasankawasan tempat tinggal lainnya, kawasan mixed-use juga mempunyai beberapa karakteristik yang membedakannya dengan kawasan tempat tinggal lainnya.Diminati Karena Integrasi Kawasan Penggabungan tiga atau bahkan lebih dari fungsi urban dalam kawasan mixed-use, membuatnya diminati oleh berbagai kalangan. Mulai dari calon pembeli yang ingin tinggal di sana, sampai pengunjung-pengunjung tidak tetap yang tertarik dengan pusat perbelanjaan, hotel, atau fungsi-fungsi lain dari kawasan mixed-use yang ditawarkan. Kehadiran kawasan mixed-use juga bisa meningkatkan gengsi dan minat orang-orang untuk bisa tinggal di dalam maupun kawasan sekitarnya. Kondisi ini otomatis mengerek harga jual properti di kawasan mixed-use dan di daerah-daerah sekitarnya yang masih dalam jangkauan. Minat yang tinggi ini karena gaya hidup praktis yang ditawarkan. Dengan bisa tinggal di sana, bekerja, melakukan rekreasi, atau bahkan mengenyam pendidikan dalam satu kawasan yang sama, ruang publik juga sebagai aspek penting dalam kawasan yang dapat menunjang berbagai kegitan umum dan bersama.

Kata kunci: bangunan mix use, ruang publik, pola zoning
\end{abstract}

\begin{abstract}
Innovation and creativity are needed to integrate all types and functions of property into one development area, namely mixed use development. In Indonesia, this concept has actually been applied for a long time, around the early 2000s when the property business experienced a boom. Basically, mixed use development is an integrated area consisting of residences, offices, shopping centers, and other urban functions. Some of the well-known mixed-use areas in Indonesia are the Ciputra World area in West Jakarta, the Central Park area in South Jakarta, the Plaza Indonesia area in Central Jakarta, the Gandaria City area in South Jakarta and District 8 in South Jakarta. Like other residential areas, mixed-use areas also have several characteristics that distinguish them from other residential areas. Interested for Area Integration The combination of three or even more urban functions in a mixed-use area makes it attractive to various groups. Starting from potential buyers who want to live there, to nonpermanent visitors who are interested in shopping centers, hotels, or other functions of the mixed-use area offered. The presence of mixed-use areas can also increase the prestige and interest of people to be able to live in and around the area. This condition automatically raises the selling price of properties in mixed-use areas and in surrounding areas that are still within reach. This high interest is due to the practical lifestyle it offers. By being able to live there,
\end{abstract}


work, do recreation, or even get an education in the same area, public space is also an important aspect in the area that can support various public and shared activities.

Keywords: mixed use buildings, public spaces, zoning patterns.

\section{PENDAHULUAN}

Pengembangan infrastruktur publik semakin marak di perlukan guna mendorong tumbunhnya kegiatan yang beragam secara terpadu dan memberikan kerangka Yang luas bagi inovasi perancangan bangunan dan lingkungan, bangunan - bangunan penunjang aktivitas public bagi masyarakat sangat berpengaruh terhadap perkembangan perekonomi negera.sehingga semakin banyak muncul bangunan bangunan seperti hotel, mall, apartemen, perkantoran ataupun retail office dalam satu kawasan atau di sebut bangunan mixed use building, Mixed use buiding sendiri memiliki artian sebuah bangunan yang mempunyai beberapa aspek fungsi yang di golongkan menjadi satu tempat, banyak penggabungkan beberapa fungsi daam bnagunanya seperti hunian, perkantoran, tempat tinggal,rental office, dan mall bahkan fasilitas bisnis dan rekreasi juga di upayakan dalam kawasan tersebut. (Indonesiaapartment, Esti Savitri 2007)

Mixed use building juga merupaka suatu upaya pembangunan yang dapat sekali mengefisiensi tempat atau lahan banyak bangunanya yang di buat tinggi dan menggabungkan suatu kegiatan dalam satu empat adalah cara efektif untuk megaefesiensika waktu kita tidak perlu jauh untuk menjapai tujuan yang berbeda namun sudah ada fasikitas lengkap dengan berbagai jenis dalan sebuah kawsan yang pastinya dirancang sebaik mungkin untuk membuat para pengguna nyaman melakukan segala jenisnya disitu. (Panduan Perancangan Bangunan Komersial, Endy Marlina 2008)

Membuka lapangan kerja baru di luar kalangan profesional yang bekerja di gedung gedung perkantaran di kawasan mixed use, kehadiranya juga menambah perekonomian menjadi semakin kencang. Kebutuhan untuk karyawan, keamanan, dan staf di berbagai gedung, pusat perbelanjaan, sekolah, supermarket, dan bagian-bagian lain dari kawasan mixed-use membuat warga sekitar memiliki kesempatan untuk mendapatkan pekerjaan. Tak hanya itu, peluang besar juga bisa dirasakan oleh penyedia jasa desain interior rumah minimalis untuk mendesain hunianhunian yang ada di kawasan ini. Belum lagi dengan adanya perkantoran, tempat tinggal, dan pusat perbelanjaan,akan muncul bisnisbisnis yang berusaha memenuhi kebutuhan warga yang tinggal atau bekerja di kawasan mixed-use. Mulai dari warung makan, tempat jasa fotokopi, minimarket, restoran, kafe, dan bisnis-bisnis pendukung bangunan mixed use building memiliki beberapa ciri ciri untk membedakan dengan bangunan atau kawasan lainya terdiri dari3 fungsi bangunan atau lebih dalam kawasanya misalnya appartement,hotel theme park, mall, hunian ,retail dan office yang tergabung dalam satu tempat dan saling terhubung terdapat pula pengintegrasian fungsi fungsi yang terdapat didalam kawasanya tersebut.

Hubungan yang relatif dekat antar satu dengan yang lainya dan saling terkoneksi satu sama lain untuk membentuk pola zona bangunan yang baik dan benar antara bangunan luar ataupun bangunan dalam.

Hadirnya bangunan mixed use ini dengan konsep yang mewadahi memiliki banyak dampak positif unuk berbagai kalangan, beberapa dampak tersebut seperti:

1. Memberikan sarana dan prasana untuk masyarakat yang lebih ekonomis dan efisien.

2. Kegiatan yang beragam dalam satu wadah yang dapat menampung segala aktifitas.

3. Mengolah lagi sistem sirkulasi.

4. Memberikan inovasi baru bagi perancangan yang lebih suistainable.

Bangunan mixed use khususnya pada ruang publik memiliki beberapa karakteristik yang mewadahi seperti:

1. External public space yaitu dapat di capat segala pihak karena tempatnya yang terbuka contoh: taman alun alun kota dan sebagainya

2. Internal public space yaitu area di dalam 
suatu bangunan contohnya dalam mix use ada loby hotel, loby appartemen theme park, galeri dan museum dan lainya

External dan internal 'quesi" gabungan antara publik dalam dan publik luar pada jenis ini di berbagai saran publik yang umum, seperti restoran, perbelanjaan, dan lain sebagainya

\section{TINJAUAN TEORI}

Ruang publik adalah ruang untuk beraktifitas semua orang secara bersama dalam konteks ruang terbuka ataupun ruang yang tertutup yang dapat di akses ataupun i kunjungi oleh semua orang, siapaun dapat memasuki area tersebut, bentuk ruang publik biasany menyesuaika kebutuh pola aktifitas pengunjunganya adapun penekanan dalam ruang publik biasanya terdapat pada jenis pengguna sirkulasi pengguna dan bentuk aktivitas yang dilakukan oleh pengunjung.

Tipologi ruang publik dapat berupa area hijau, taman ruang terbuka, perbelanjaan ataupun hunian square pasar, mall dan lainya pendekatan ruang publik ada 2 aspek diantara ruang publik pasif dan ruang publik aktif, ruang publik pasif adalah ruang publik yang hanya orang tertentu dengan tujuan yang ada mereka datangi contohnya loby, appartemen, loby hotel dan lainya sedangan ruang publik aktif adalaha ruang publik yang sering didatangi seluruh orang baik berkepentingan maupun hanya sekedar menhirup udara atau mencari udara segar saja, contohnya taman, alun alun dan ruang terbuka lainya karena tidak terdapat batasan apapun dalam ruag publik jenis ini.

Ruang publik mempunyai beberapa tipe pola dalam penerapanya yaitu: Linear, terpusat, cluster radial dan grid.

\section{METODE PENELITIAN}

Metode yang dilakukan yaitu deskriptif dengan pendekatan kualitatif. Pendekatan kualitatif menurut Sugiyono (2017:9) adalah "metode penelitian yang berlandaskan filsafat postpositivisme, digunakan untuk meneliti pada kondisi obyek yang alamiah". Artinya data yang dikumpulkan buka berupa angka-angka, melainkan data tersebut berasal dari naskah, study internet, study fakta,dokumen pribadi, catatan memo, dan dokumen resmi lainnya.

Penelitian deksriptif bertujuan untuk menjabarkan apa yang saat ini berlaku ( Mardalis, 2008:h.26) didalamnya terdapat upaya mendeskripsikan, mencatat, analisis dan meninterprestasikan kondisi yang sekarang ini terjadi atau ada.

Jadi tujuanya untuk menunjukan real yang terjadi dalam tapak merupakan suatu potensi yang berkembang pendekatan kualitatif dalam penelitian ini mencocokn atau menguraikan teori yang ada ke dalam tapakmanakah yang lebih mengarah pada salah satu teori yang ada seperti analisa studi banding danstudi literatur.

Objek dalam penelitian ini adalah faktorfaktor yang mempengaruhi pola zona publik pada kawasan mixed use sedangkan subjek dalam penelitian ini adalah:

1. Ciputra World I dan 2 (jakarta barat

2. Central Park ( jakarta Selatan)

3. Plaza Indonesia (jakarta pusat)

\section{PEMBAHASAN}

\section{Ciputra World Jakarta Barat}

Citra word jakarta selatan adalah bangunan mega super blok Yang berda di kawasan jl. Dr satrio kuningan timur setia budi jakarta selatan, Ciputra word jakarta terdiri dari tiga superblok, yaitu Ciputra word 1 jakarta di, ciputra word 2 jakarta, dan ciputra word 3 jakarta, dengan total luas tanah 15 hektar yang akan dirancang menjadi 15 tower

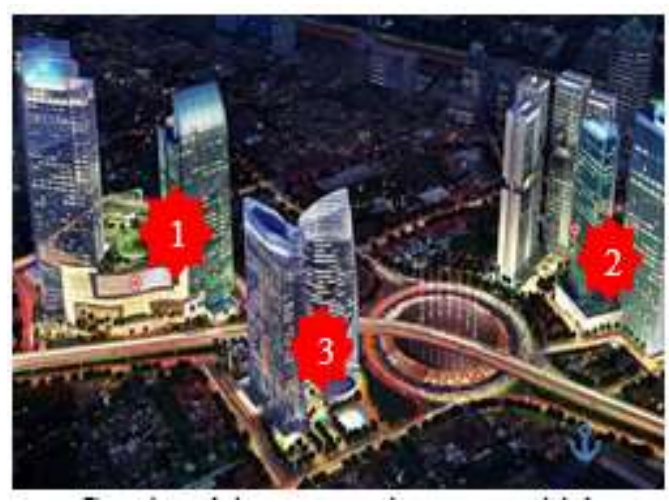


Gambar 1 kawasan ciputra world 1 Sumber: internet

Cipura world satu memiliki beberapa fungsi Diantaranya gedung mall yang terletak diantara dia menara di ciputra dan ada hotel yang terletak di menara 1 dan juga appartement yang terletak di menara 2 ,ciputra world 1 ini menggunakan sistem penatanaan grid dan pendekatan arsitektuk modern didalam bangunan juga mengupayakan bangunan green arsitektur dengan emanfaatan panel panel surya untuk menangkap cahaya matahari dan di jadikan sebagai suplay cadangan listrik, cipurta world dibuat untuk memenuhi gaya kebutuhan hidup masyarakan yang lebih efisien dalam satu tempat.

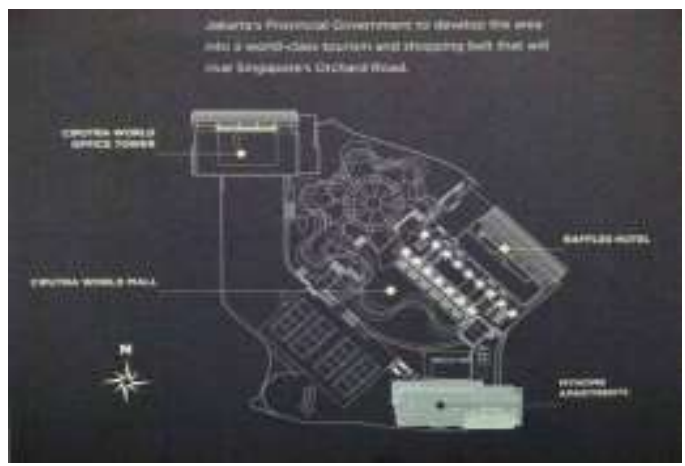

Gambar 2 site plan ciputra world 1 Sumber: DK Ching form space and order hal 278

Ciputra world 1 mengusung konsep "Green Building Design" (desain bangunan ramah lingkungan) yang sekaligus menjadi proyek office tower terakhir yang akan didirikan di area tersebut. Bangunan akan mendapatkan sertifikasi green building dari Green Building Council Indonesia seni internasional, hal ini ditunjukkan dengan konsep CAC yang terdiri dari ciputra word 1 memiliki 2 gedung menara yang di fungsika menjadi hotel dan appartement, dan sebuah mall yang terletak diantara 2 menara bangunan yang menggapitnya akses yang mudah kawasanya mempunyai tempat parkir sendiri sehingga tidak perku terlalu jauh dari parkir kawsanya menuju ke masing masing gedung bisa langsung diakses dengan mudah.

- Analisa Ruang Publik Bersama

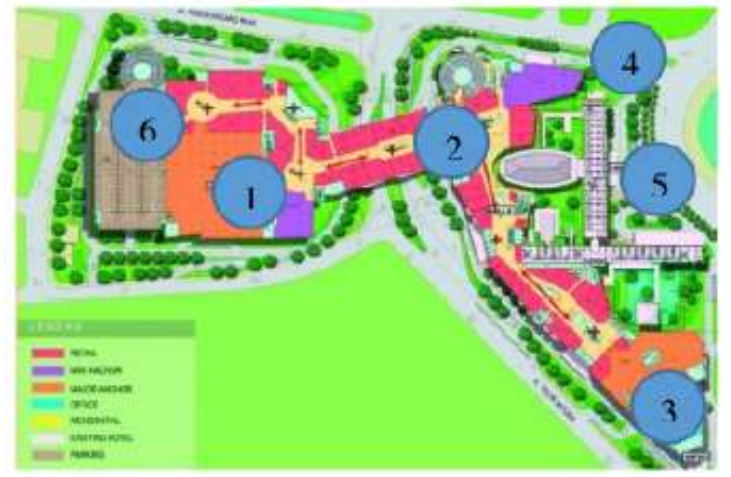

Gambar 3 pola ruang pada site

Sumber: jurnal kaawasan ciputraworld
Keterangan:

$\begin{array}{ll}\text { 1. Appartemen } & \text { 4. Galeri } \\ \text { 2. Mall } & \text { 5. Hotel } \\ \text { 3. Office / kantor } & \text { 6. Parkir }\end{array}$
3. Office / kantor 6. Parkir

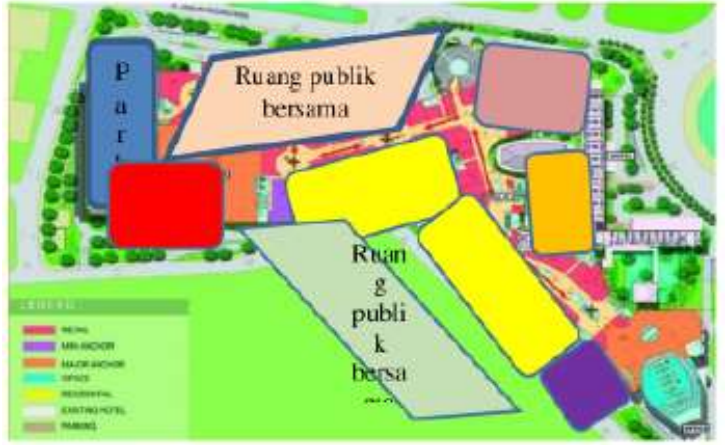

Gambar 4 ruang publik

Sumber: jurnal kaawasan ciputra world

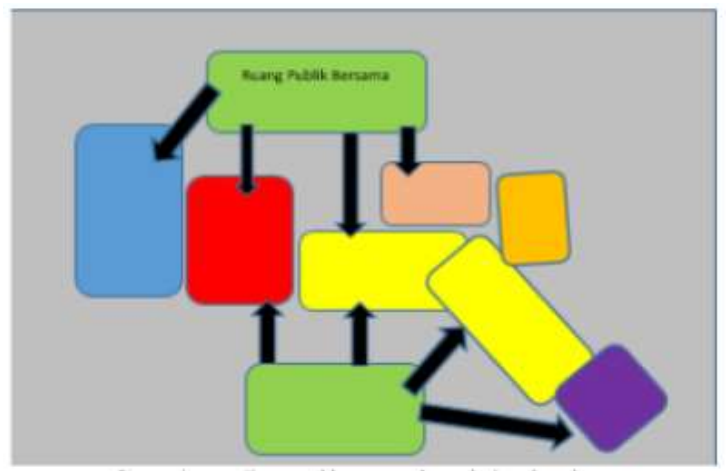

Gambar 5 analisa pola sirkulasi

Sumber: jurnal kaawasan ciputra world

Analisa Ruang Publik Masing-Masing

1. Appartement 


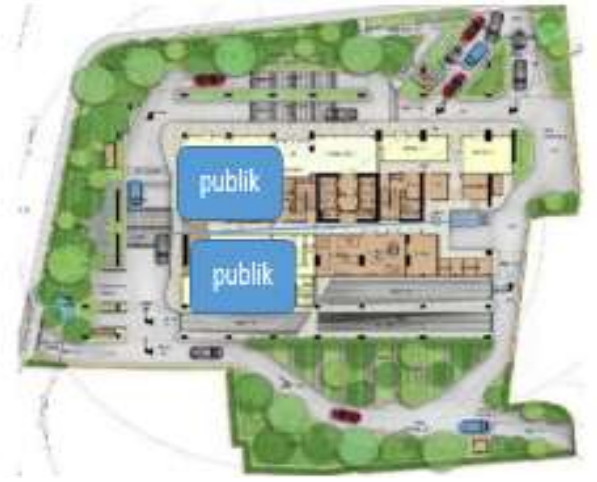

Gambar 6 ruang publik pada apartement Sumber: jurnal kaawasan ciputra world

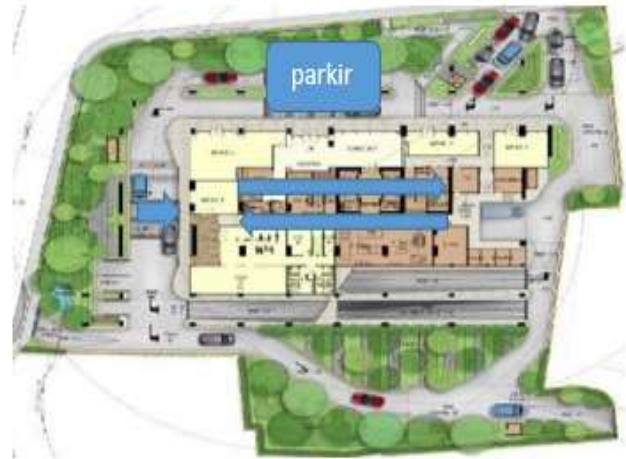

Gambar 7 sirkulasi ruang publik Sumber: jurnal kaawasan ciputra world

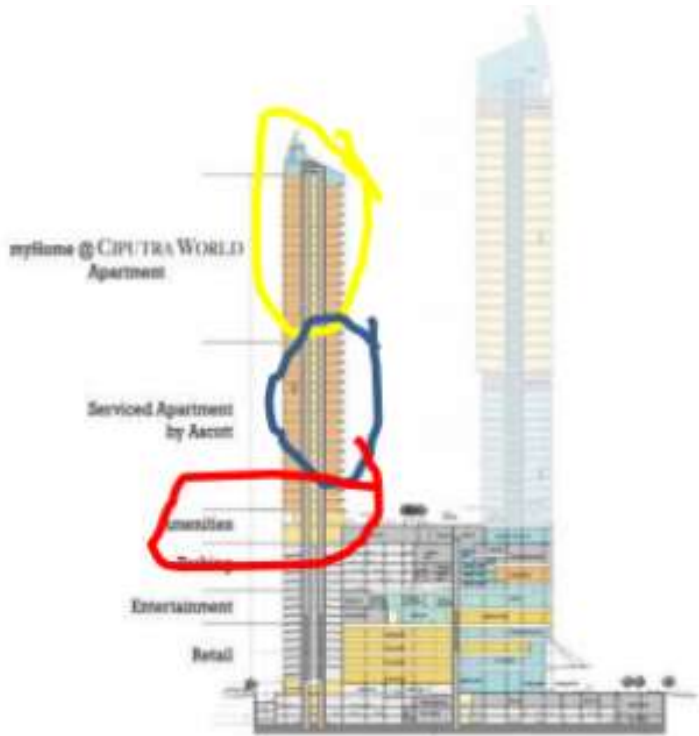

Gambar 8 zoning vertikal apartement Sumber: jurnal kaawasan ciputra world

2. Mall

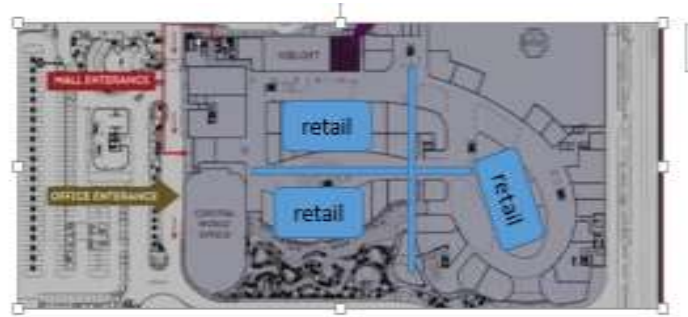

Gambar 9 ruang publik mall Sumber: jurnal kaawasan ciputra world

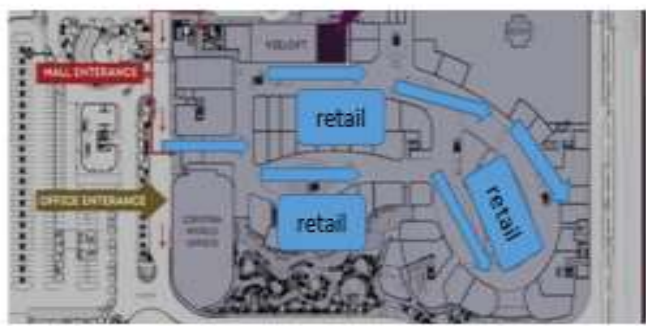

Gambar 10 pola ruang Sumber: jurnal kaawasan ciputra world

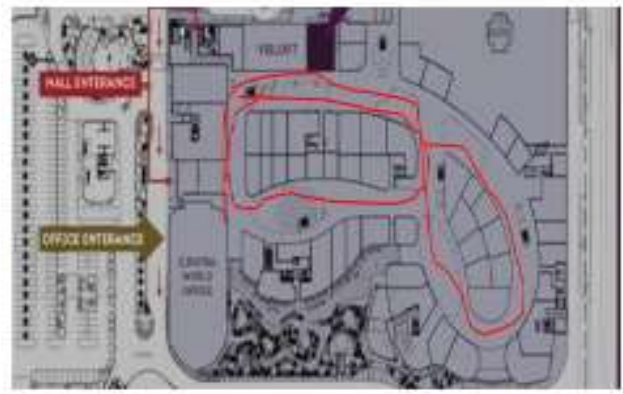

Gambar 11 pola sirkulasi Sumber: jurnal kaawasan ciputra world

3. Office

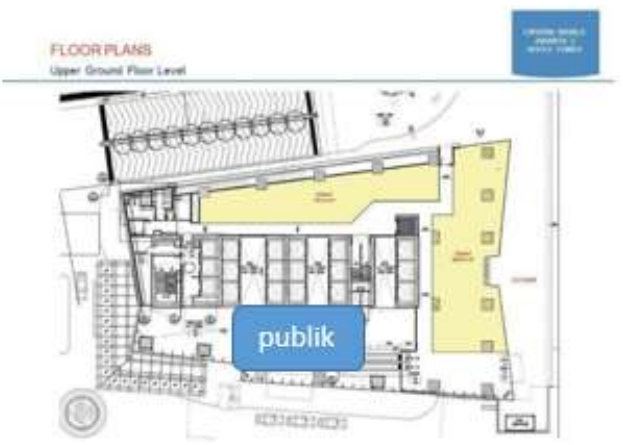

ambar 12 ruang publik office

G Sumber: jurnal kaawasan ciputra world 


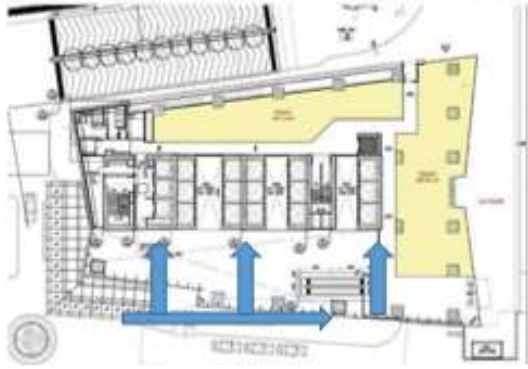

Gambar 13 ruang publik office Sumber: jurnal kaawasan ciputra world

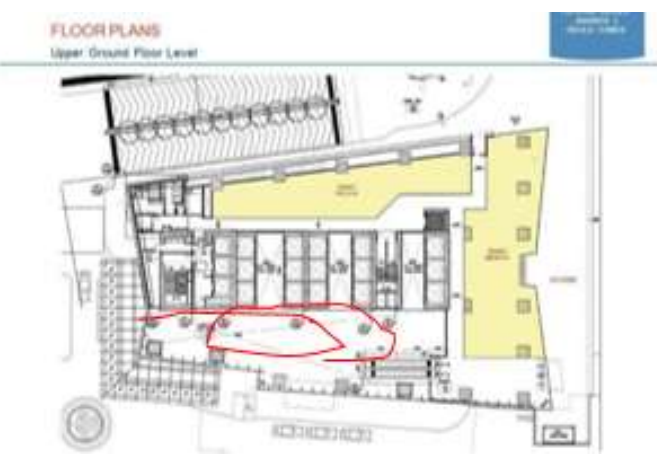

Gambar 14 ruang publik office Sumber: jurnal kaawasan ciputra world

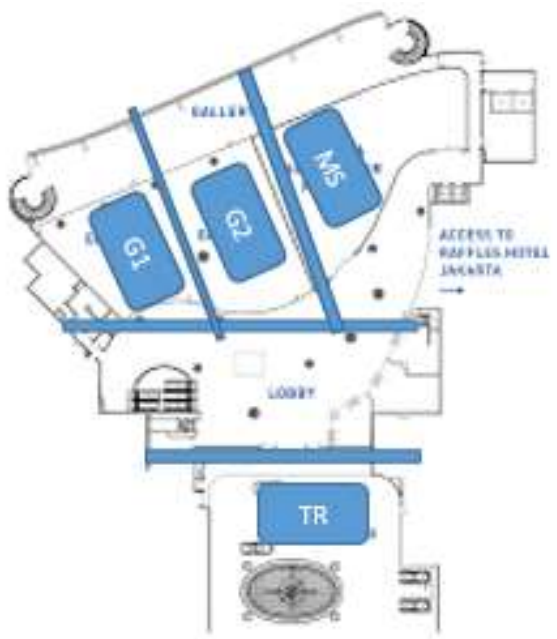

Gambar 15 pola zoning Sumber: jurnal kaawasan ciputra world

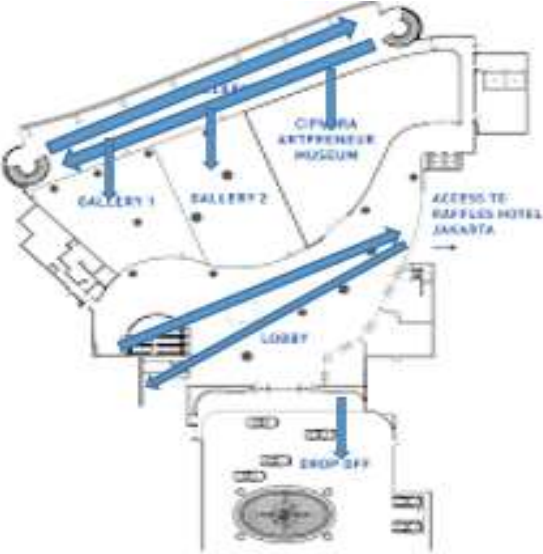

Gambar 16 pola zoning Sumber: jurnal kaawasan ciputra world

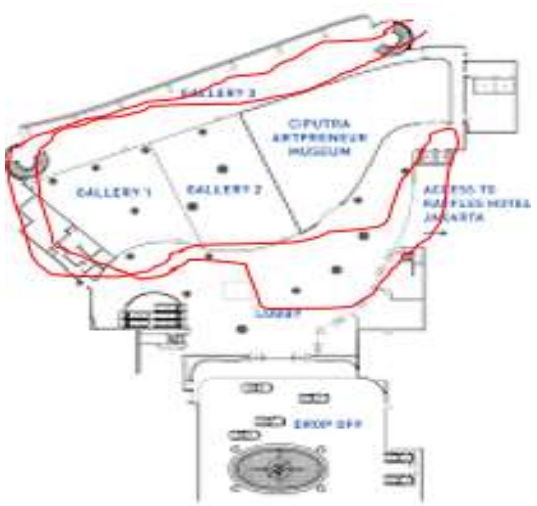

Gambar 17 pola zoning Sumber: jurnal kaawasan ciputra world

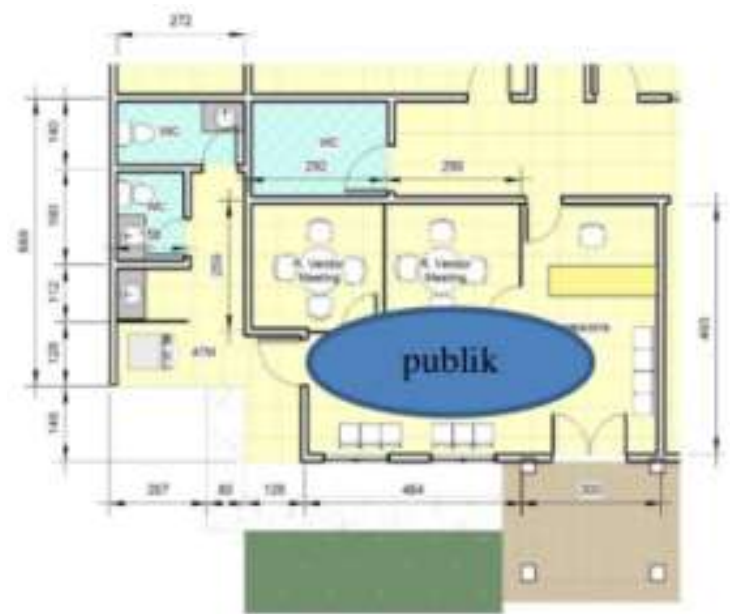

Gambar 18 ruang publik hotel Sumber: jurnal kaawasan ciputra world 


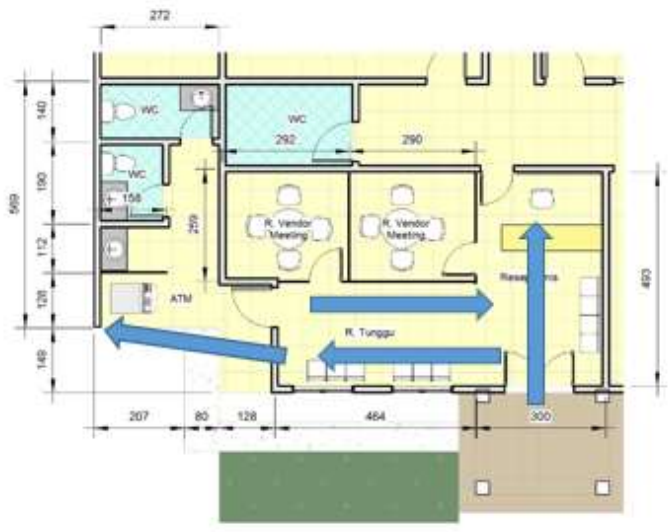

Gambar 19 ruang publik hotel Sumber: jurnal kaawasan ciputra world

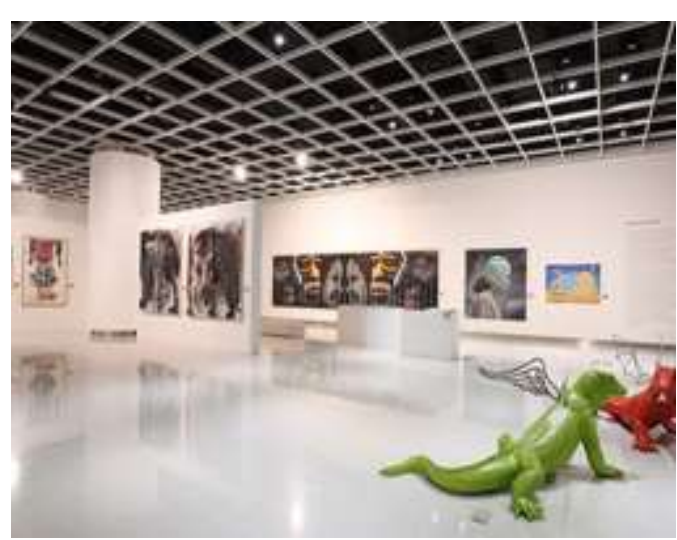

Gambar 20 ruang galeri Sumber: internet

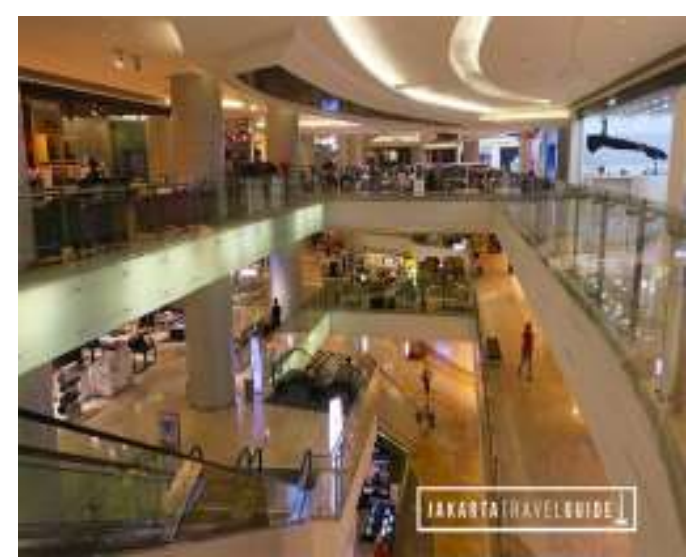

Gambar 21 atrium mall Sumber: internet

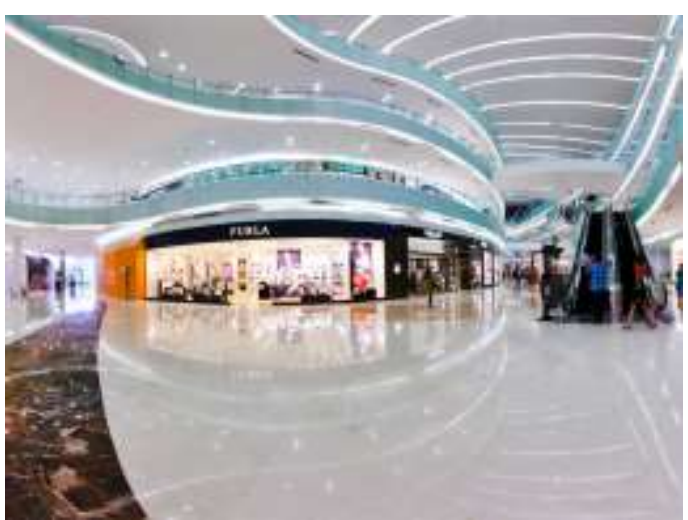

Gambar 22 atrium mall Sumber: internet

\section{Ciputra World II}

Dalam kawasan ini terdabai beberapa fungsi yaitu perkantoran ,appartement, dan hunian yang di gabung menjadi satu hunian dapat di menara ketika kantor ada di menara petama, dan appartemen berada di menara kedua ,kawasan ciputra word 2 ini sangat modern di dalam bnagunan yang sudah menggabungkan beberapa 3 dalam kawasan sebagai penunjang kebutuhan hidup masyarakat metropolitan yang memerlukan fasilitas yang nyaman dalam jarak yang dekat supaya bisa efisiensi waktu dalam berpindah aktivitas

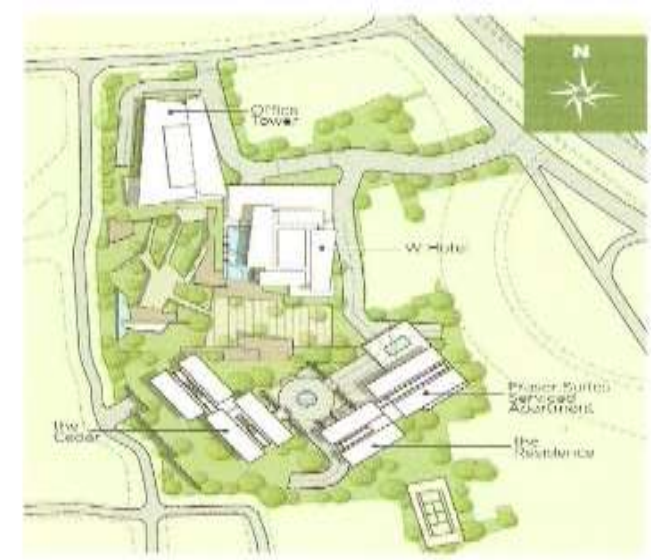

Gambar 23 site plan ciputra world 2 Sumber: internet 
Ciputra World 2 Terletak di kawasan keuangan dan perbelanjaan yang sedang, Ciputra World 2 Jakarta akan menjadi ikon prestise, kenyamanan hidup dan desain mewah di Jakarta. Pada fase 1, akan ada dua menara kondominium strata title dan satu apartemen berstandar emas yang dikelola oleh Frasers Hospitality yang diakui secara internasionalCiputra World 2 Jakarta dirancang oleh SCDA, Tim telah menerapkan 1st pionir Interlocking Loft Concept di Indonesia dengan unit yang sangat terbatas. Hasilnya adalah unit bergaya mezzanine dengan langit-langit 7 meter dan akses dari dua lantai, memberikan ruang tamu yang lebih luas dan fungsional.

Setiap menara kondominium memiliki infinity pool di Sky Garden, sebuah ruang terbuka dengan panorama kota yang menakjubkan. Juga setiap menara memiliki fasilitas sendiri seperti perpustakaan, gym, sauna \& spa, ruang multifungsi, area barbeque, taman bermain anak-anak. Dengan alasan, kompleks ini dikelilingi oleh taman rimbun lanskap yang dilakukan secara profesional. Fasilitas ini dibuat untuk menyediakan lingkungan yang dirancang dengan indah yang memenuhi persyaratan yang tepat dari pemilik rumah yang paling cerdas. Ini adalah tempat tinggal yang tak tertandingi.

- Analisa Ruang Publik Bersama

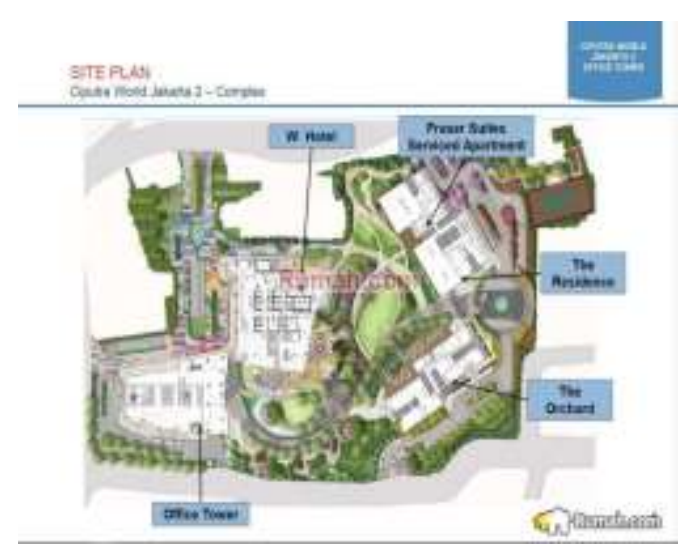

Gambar 24 analisa ruang publik Sumber: internet

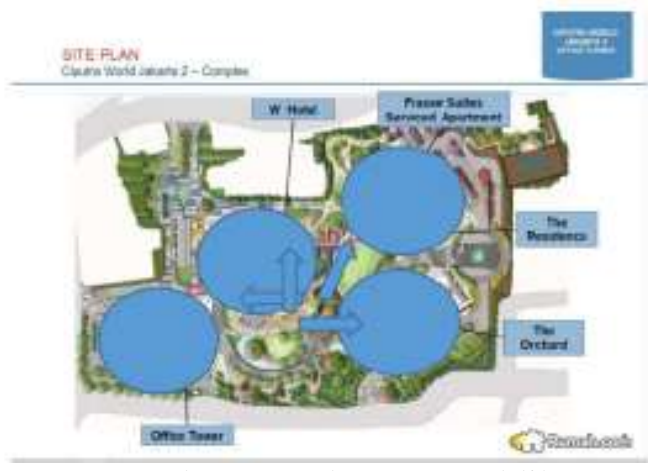

Gambar 25 pola ruang publik Sumber: internet

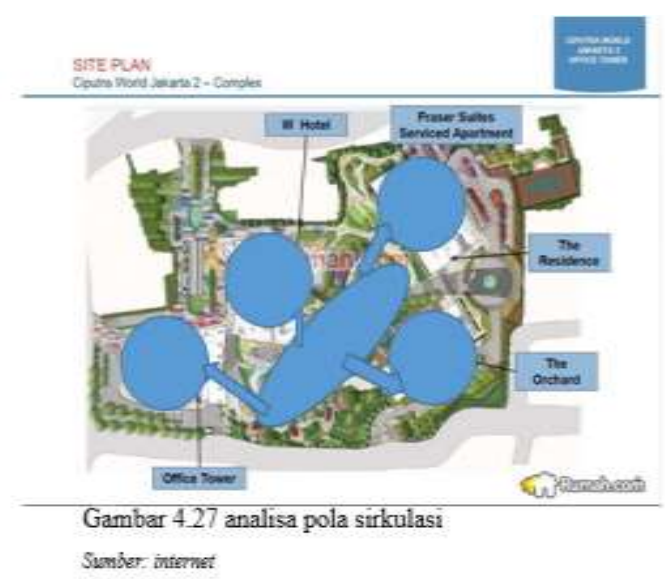

Gambar 26 analisa pola sirkulasi Sumber: internet

- Analisa Ruang Publik Masing Masing

1. Office Tower

Small Office Floor Plan

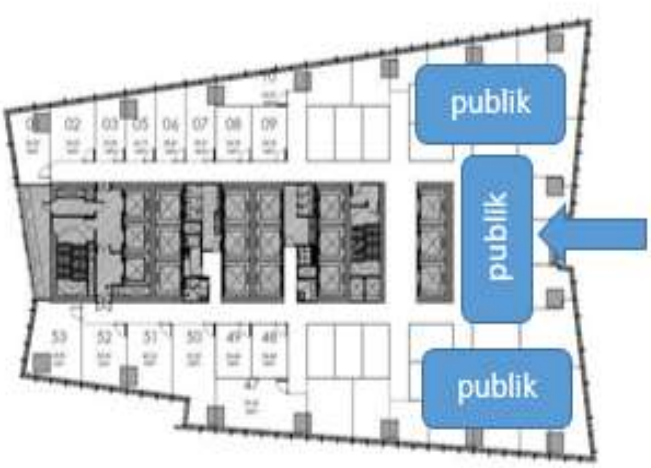

Gambar 27 analisa ruang publik Sumber: internet 


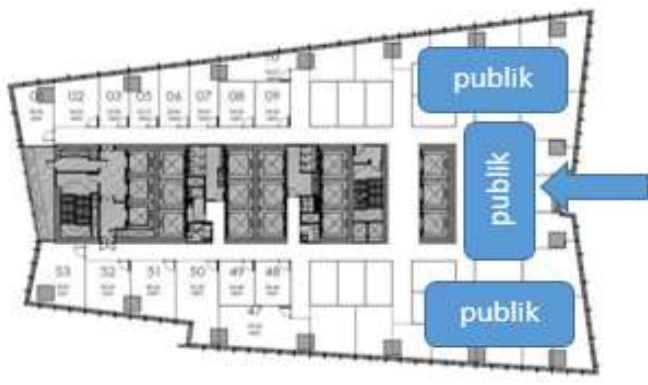

Gambar 28 pola sirkulasi Sumber: internet

2. Hotel

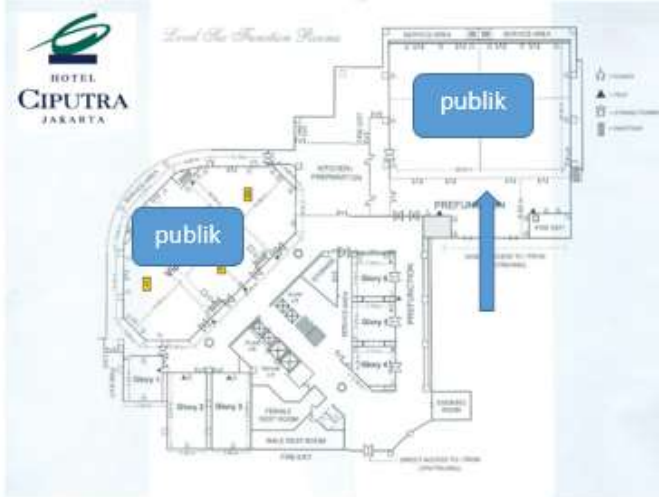

Gambar 29 analisa ruang publik Sumber: internet

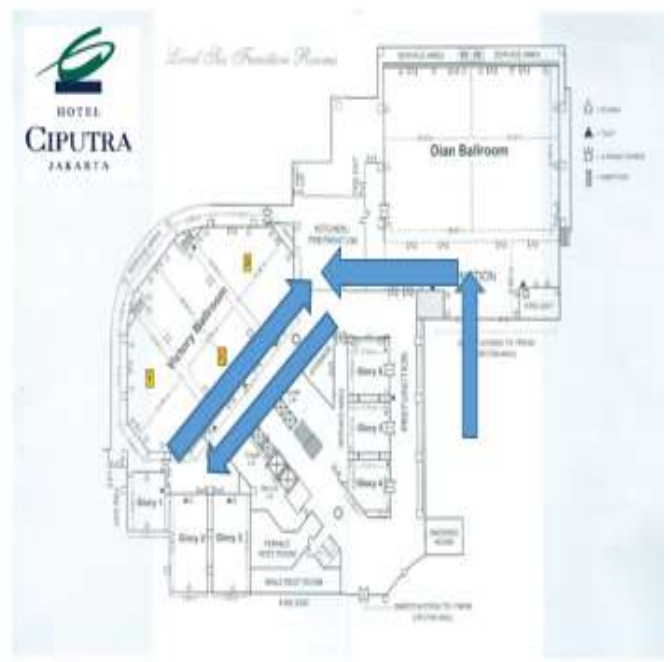

Gambar 30 sirkulasi ruang publik Sumber: internet

3. Appartement dan orchad condominium

\section{Floorplan}

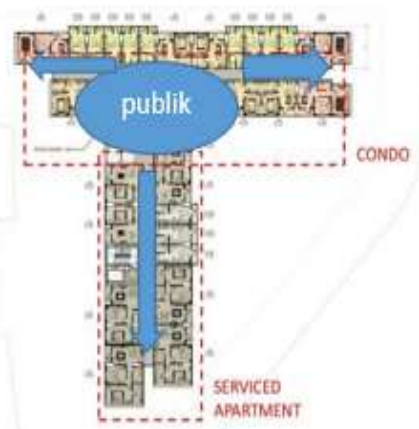

Gambar 31analisa ruang publik Sumber: internet

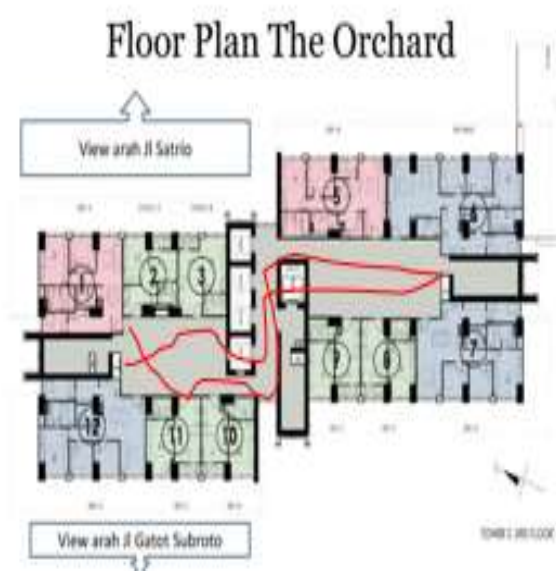

Gambar 32 sirkulasi ruang publik Sumber: internet

\section{Floor plan The Suites}

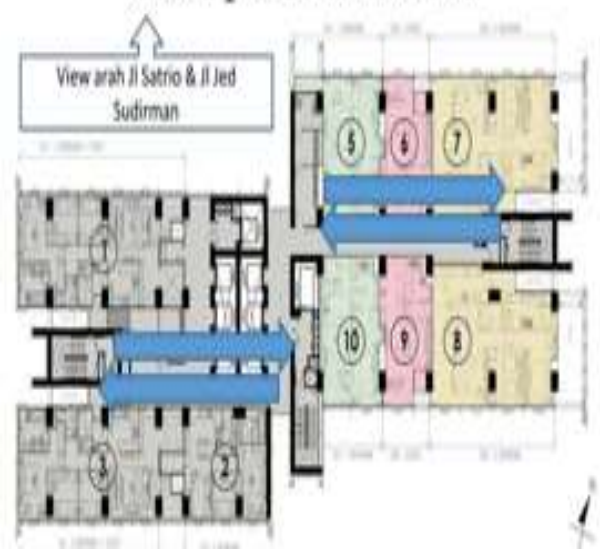

Gambar 33 pola zona ruang publik Sumber: internet 


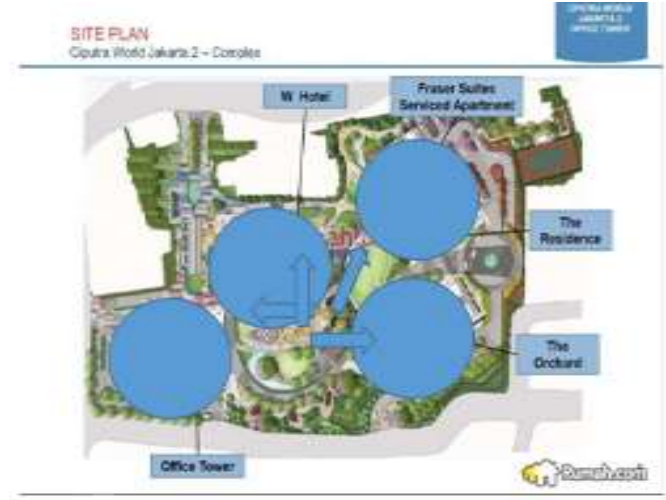

Gambar 34 loby appartement Sumber: internet

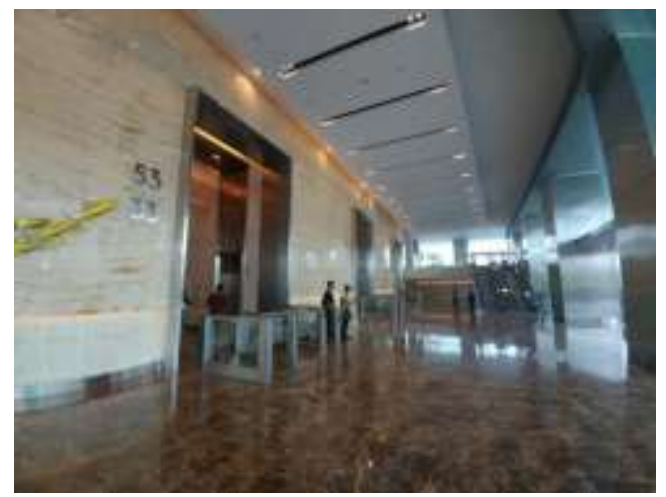

Gambar 35 loby apartement Sumber: internet

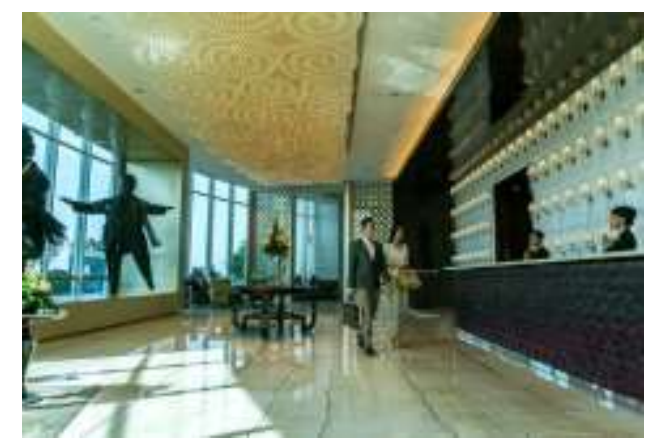

Gambar 36 loby kantor Sumber: internet

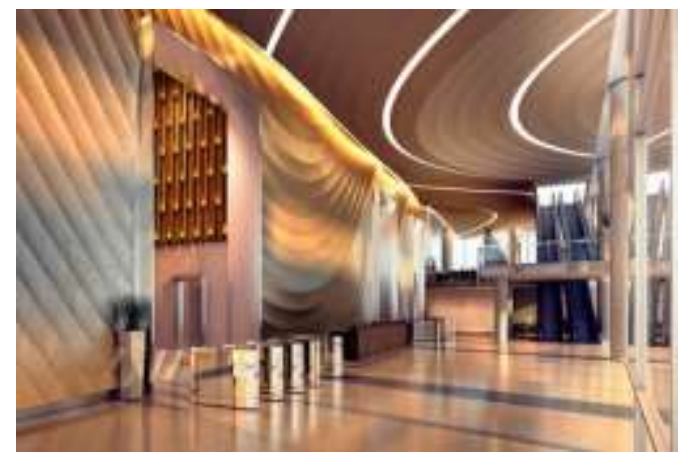

Gambar 37 loby hotel Sumber: internet
4. Central park

Central park merupakan kawasan mix use yang unik di karena terdapat theme park yang bisa dijadikan sebagai tempat wisata bagi para pengunjung tak hanya itu central park juga memiliki bangunan lain yang berfungsi sebgai Mall , appartement dan kantor. Dalam kawasan juga terdapat 2 theme park autdor dan indor yang dapat menjadi pemandangan indah dan tempat berwisata di dalam sebuah kota untuk menghabiskan aktivitas di akhir pekan bersama keluarga

- Analisa ruang publik bersama

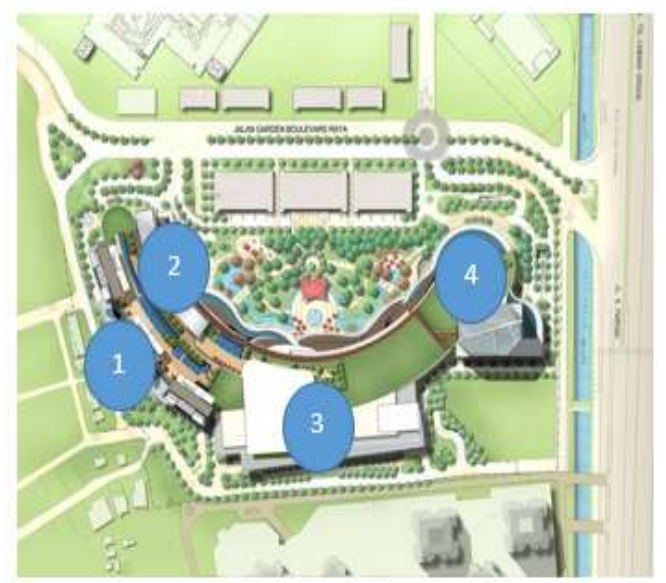

Gambar 38 gambar site plan central park

Sumber: certral park building and design

\section{Keterangan : \\ 1. Appartement 3. Them \\ 2. Hotel 4. Mall}

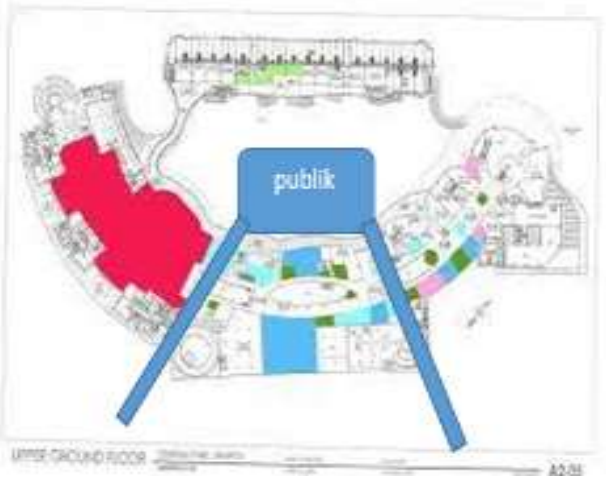


Gambar 39 denah site plan centrapark Sumber: certral park building and design

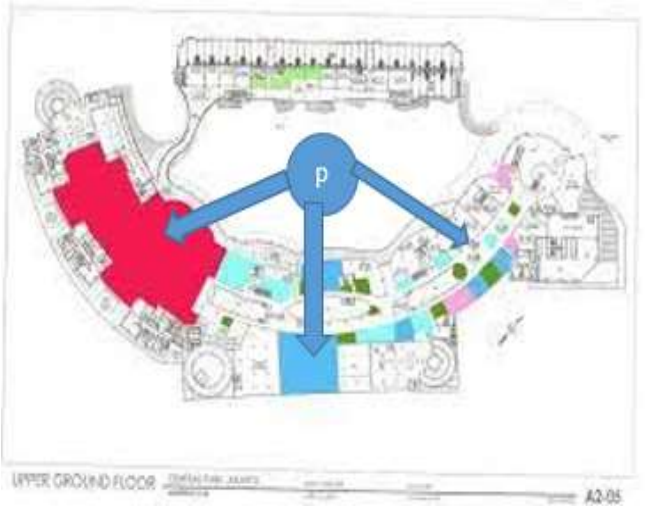

Gambar 40 Analisa ruang publik Sumber: certral park building and design

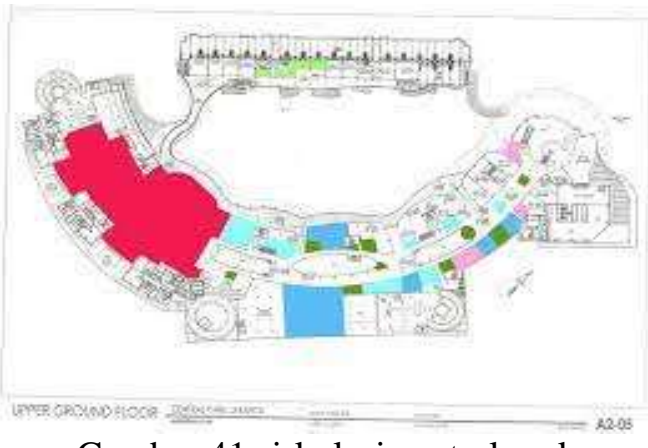

Gambar 41 sirkulasi central park Sumber: certral park building and design

- Analisa ruang masing masing

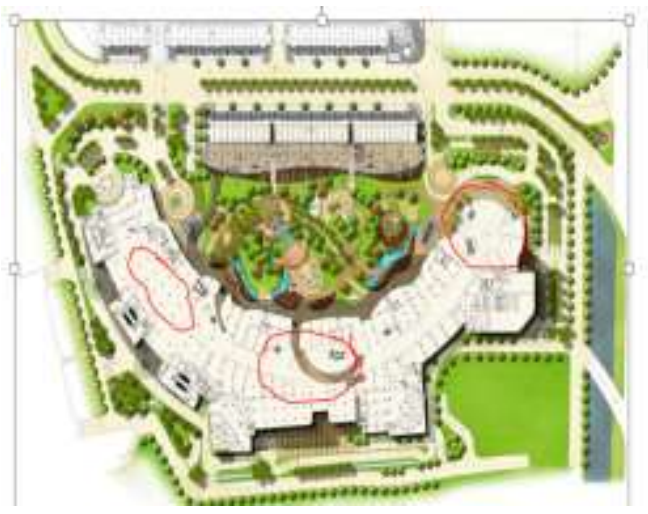

Gambar 42 ruang publik pada 3 bagian Sumber: certral park building and design

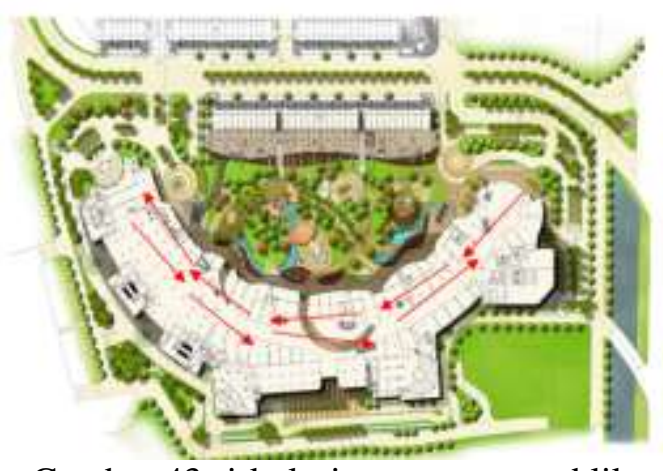

Gambar 43 sirkulasi ruang antar publik Sumber: certral park building and design

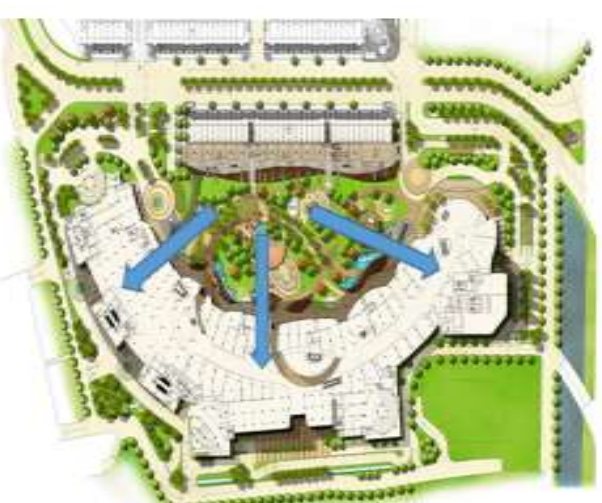

Gambar 44 analisa pencapaian Sumber: certral park building and design

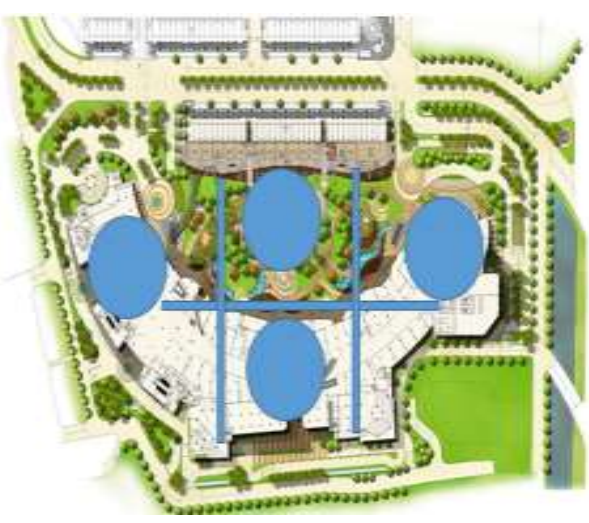

Gambar 45 pola ruang publik Sumber: certral park building and design 


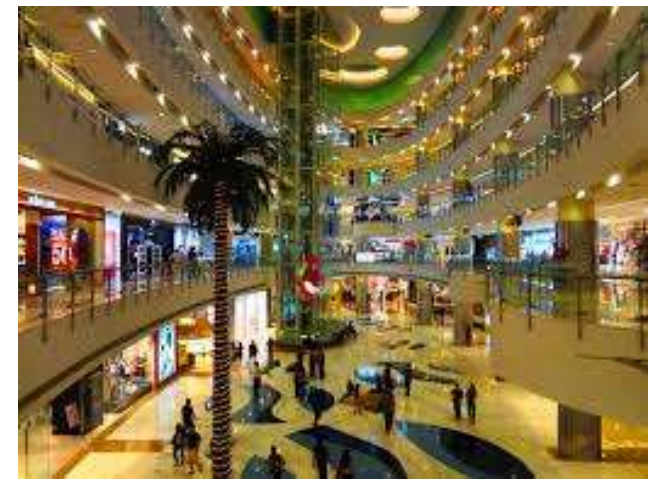

Gambar 46 atrium mall

Sumber: certral park building and design

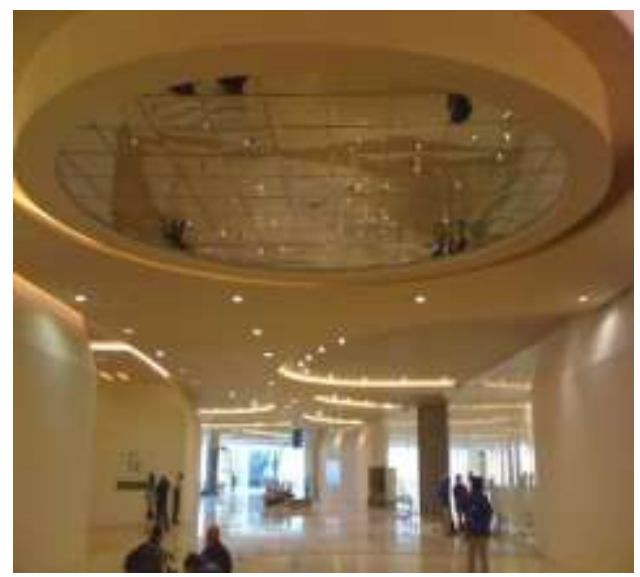

Gambar 47 indor theme park Sumber: certral park building and design

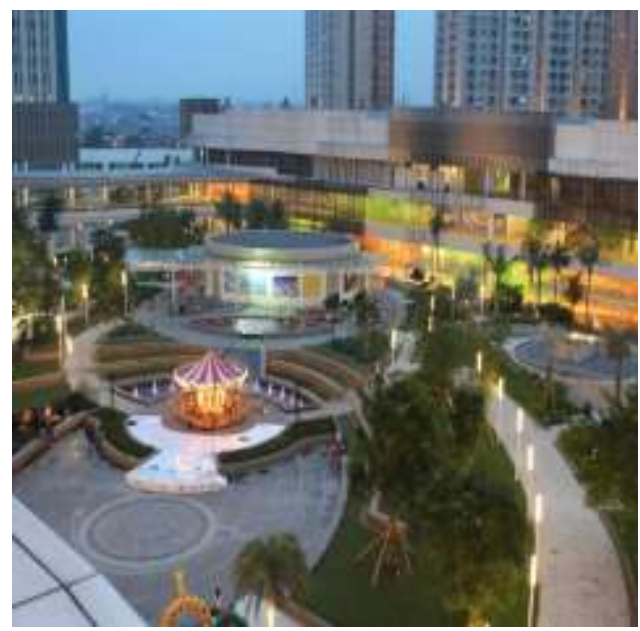

Gambar 48 outdor theme park Sumber: certral park building and design
5. Plaza indonesia

Plaza Indonesia merupakan kawasan mixed use yang menjadi salah satu ikon di Jakarta. Kawasan ini menawarkan berbagai area hotel, pusat perbelanjaan, perkantoran dan apartemen. Adapun area tersebut yaitu, grade hyat Jakarta, Plaza Indonesia Shopping Center dan Keraton at The Plaza

- Analisa ruang publik bersama

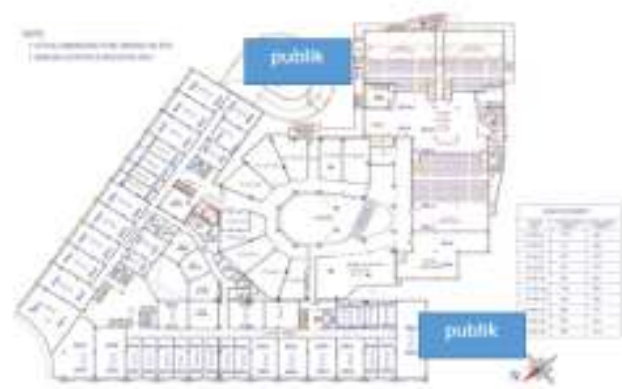

Gambar 49 site lane plaza indonesia Sumber: concept and desain mall

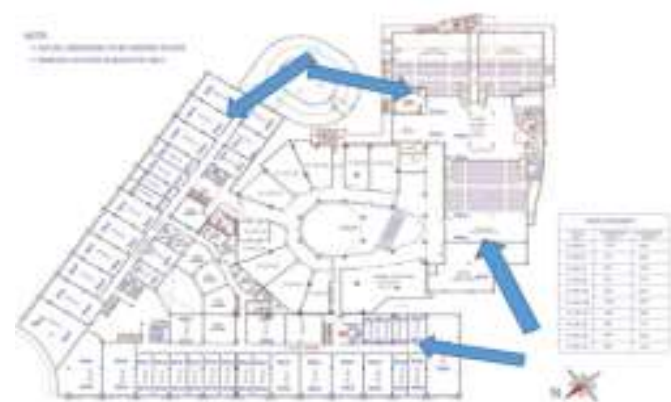

Gambar 50 Analisa pola sirkulasi Sumber: concept and desain mall

- Analisa ruang publik masing masing

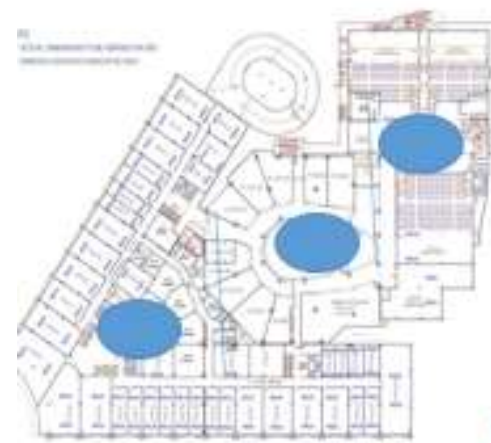


Gambar 51 pola ruang

Sumber: concept and desain mall
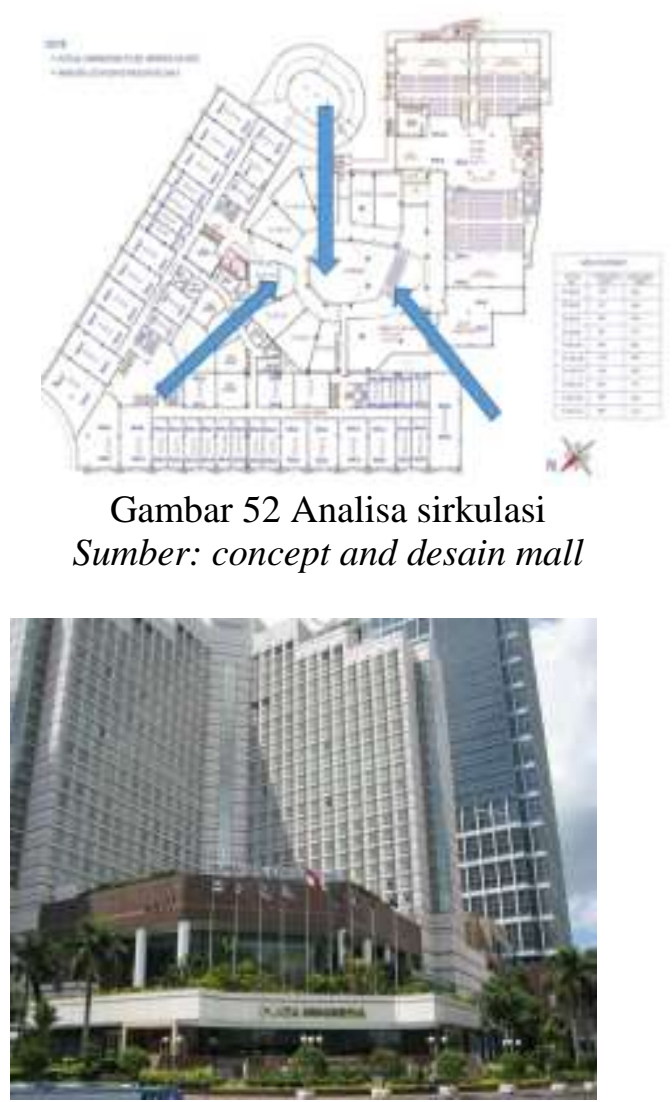

Gambar 54 gedumg plaza

Sumber: concept and desain mall

\section{KESIMPULAN}

1. Dalam perancangan kawasan mix use pola zoning yang sering gunakan yaitu pola linear, cluster dan radial

2. Hubungan keruang yang di gunakan pass by sopace yaitu membawa pengunjung melewati beberapa ruang, pass trough space membaa pengunjung melewatu ruang dalam ruang, termnate in a space membawa pengunjung langsung menuju tempat tujuan

3. Pola ruang menggunakan use of space yang menunjukan ruang publik berdasarkan aktifitas dan fungsinya, dan

4. 4.menggunakan space form and contek yaitu menunjukan ruang publik yang menari sesuai dengan funsinya

5. Pola sirkulasi direct menuju langsung, curvalinear berliku likusebelum ke tempat tujuan.
6. Dari segi kenyaman dalam ruang publi menggunakan pendekatan variety aspek, permeabelity aspek dan legability aspek.

7. Sirkulasi pengunjung yang beragam berdasarkan bentuk bangunan

8. Terdapat beberapa bangunan publik pembeda seperti theme park dan galeri sebagai icon unik yang ada di kawasan tersebut

9. Fasiitas parkir bersama dan parkir masing masing yang cukup mewadahi di eberaa kawasan

10.Terdapat bangunan office dan apartement yang selalu ada dalam kawasan mix use

11.Bagunan penunjang publik yang sudah sesuai standar perencanaan dalam kaidah arsitektur dari segi fasilitas yang di paparkan ke pada pengunjung.

\section{DAFTAR PUSTAKA}

Alfian, joseph rangkung, reny syafriny(2003) symbiosys architecture

Savitri esti (2007) indonesiaappartement

Marlina endy (2008) panduan perancangan bangunan komersial

Hilda b alexander (2008) kawasan central bisnis

Tymoti jhanis , (2010) UAJY victory

Schwankenet al, (2003) ciri ciri bangunan mixed Use

Danisworo (1996) Manfaat bangunan mixed use

Sumargo (2003) tata letak bangunan

Departement jendral perhubungan darat (19980 area parkir

Hakim rustam (1987) susunan masa bnagunan

Car dkk (1992) tipoloi ruang publik

Car (2003) carmona et al

Carmona (2003) bentuk ruang publik

Krier rob (1979) konsistensi bentuk publik

Dk ching (1996) organisasi hubungan ruang

Rapoort (1977) pola aktivitas ruang publik

Kustiawan, pontoh (2009) tata guna lahan

Siaahan (2011) karakter ruang publik

Marlina (2008) klasifikasi pusat perbelanjaan

Ruberstain (1978) pusat perbelanjaan

Ian bantley public realm

Sugiono (2017) pendekatan kualitatif

Mardalis (2008) penelitian deskriptif

Nazir (1988) study pustaka

Moelong lexy j (2002) analisa data 